\title{
Mechanical Behavior of Yttria-Stabilized Zirconia Aqueous Cast Tapes and Laminates
}

\author{
V. Moreno, ${ }^{1,2}$ R. M. Bernardino, ${ }^{1,2}$ and D. Hotza ${ }^{1,3}$ \\ ${ }^{1}$ Graduate Program on Materials Science and Engineering (PGMAT), Federal University of Santa Catarina, \\ 88040-900 Florianópolis, SC, Brazil \\ ${ }^{2}$ Department of Mechanical Engineering, Federal University of Santa Catarina, 88040-900 Florianópolis, SC, Brazil \\ ${ }^{3}$ Department of Chemical Engineering, Federal University of Santa Catarina, 88040-900 Florianópolis, SC, Brazil
}

Correspondence should be addressed to D. Hotza; dhotza@gmail.com

Received 6 December 2013; Revised 22 January 2014; Accepted 27 January 2014; Published 9 March 2014

Academic Editor: Thomas Graule

Copyright (c) 2014 V. Moreno et al. This is an open access article distributed under the Creative Commons Attribution License, which permits unrestricted use, distribution, and reproduction in any medium, provided the original work is properly cited.

Aqueous tape casting was used to produce yttria-stabilized zirconia films for electrolyte-supported solid oxide fuel cell (SOFC). Tape casting slurries were prepared varying the binder content between 20 and $25 \mathrm{wt} \%$. A commercial acrylic emulsion served as binder. Rheological measurements of the two slurries were performed. Both slurries showed a shear-thinning behavior. Tapes with $25 \mathrm{wt} \%$ binder exhibited adequate flexibility and a smooth and homogeneous surface, free of cracks and other defects. Suitable conditions of lamination were found and a theoretical density of $54 \%$ in the laminates was achieved. Laminated tapes showed higher tensile strength compared to single sheets. Tape orientation has a significant influence on the mechanical properties. Tensile strength, elongation to strain, and Young's modulus measured in samples produced in the direction of casting showed higher property values.

\section{Introduction}

The tape casting technique has been widely used to produce thin and high dense green films for multilayer ceramic packaging technology [1-6]. This is a low cost process that enables producing ceramic sheets and large flat areas commonly used in electronic applications, such as capacitors, fuel cells, piezoelectric devices, and inert and catalytic substrates [7-9]. This method allows controlling the thickness of the sheets varying between $20 \mu \mathrm{m}$ and $2 \mathrm{~mm}$. Typical tape cast slurries are prepared by dispersion of a powder in an organic or nonorganic solvent with a dispersant, followed by the addition of binders, plasticizers, and other additives. These slurries are cast through a so-called doctor blade over a flat carrier. Tape casting slips are based traditionally on organic solvent; however, in the last years there is a huge concern about the toxicity and volatility of those solvents. Aqueous systems are environmentally correct and offer lower cost [10].

Water-based slurries have some drawbacks compared with organic solvent based slurries, such as slow drying rate, tendency to flocculate, and poor wetting due to the high surface tension of the water [11-14]. A wide large amount of water soluble substances has been used to prepare tape casting slurries such as cellulose and vinyl/acrylic binders [10]. The right choice of the binder is very important, because it directly influences particle packing during the tape casting process, the mechanical and physical properties of the green tapes, and the adhesion between sheets during lamination [15]. Compared to water soluble binders, latex binders such as acrylic emulsions allowed preparing slurries with high solids and binder content without significantly increasing the viscosity and providing a short drying time and a high mechanical strength to the green tapes [13].

In this work, aqueous tape casting was used to produce yttria-stabilized zirconia films for electrolyte-supported solid oxide fuel cell (SOFC). A commercial acrylic emulsion was used as binder, and two different slurry compositions were tested. Rheological behavior was examined and the microstructure and density of the green tapes were analyzed. Tensile strength and elongation strain of the green tapes and laminates were also evaluated. 
TABLE 1: Slurry compositions.

\begin{tabular}{lcc}
\hline Component & $1(\mathrm{wt} \%)$ & $2(\mathrm{wt} \%)$ \\
\hline 8YSZ & 55 & 55 \\
Mowilith LDM 6138 & 20 & 25 \\
Darvan 821A & 1 & 1 \\
Antifoamer & 0.5 & 0.5 \\
Others & 1.5 & 1.5 \\
Deionized water & 22 & 17 \\
\hline
\end{tabular}

TABLE 2: Warm pressing conditions.

\begin{tabular}{lcc}
\hline & Level 1 & Level 2 \\
\hline Temperature $\left({ }^{\circ} \mathrm{C}\right)$ & 60 & 40 \\
Pressure $(\mathrm{MPa})$ & 19 & 16 \\
Time $(\mathrm{min})$ & 5 & 10 \\
\hline
\end{tabular}

TABLE 3: Factorial experimental design.

\begin{tabular}{lccc}
\hline Experiment & Pressure $(\mathrm{MPa})$ & Temperature $\left({ }^{\circ} \mathrm{C}\right)$ & Time $(\mathrm{min})$ \\
\hline 1 & 19 & 60 & 5 \\
2 & 19 & 60 & 10 \\
3 & 19 & 40 & 5 \\
4 & 19 & 40 & 10 \\
5 & 16 & 60 & 5 \\
6 & 16 & 60 & 10 \\
7 & 16 & 40 & 5 \\
8 & 16 & 40 & 10 \\
\hline
\end{tabular}

\section{Materials and Methods}

Tape casting slurries were prepared with 55 wt $\%$ yttriastabilized zirconia powder ( $8 \mathrm{YSZ}, 8 \mathrm{~mol} \% \mathrm{Y}_{2} \mathrm{O}_{3}$ stabilized $\mathrm{ZrO}_{2}$, Sigma-Aldrich). The powder was deagglomerated in deionized water with addition of $1 \mathrm{wt} \%$ dispersant (Darvan $821 \mathrm{~A}$, Vanderbilt) using ball milling for $24 \mathrm{~h}$. After deagglomeration, an acrylic emulsion binder (Mowilith LDM 6138, Clariant), antifoamer (Antifoamer A, Sigma-Aldrich), and surfactant (coconut diethanolamide, Stepan) were added and the slurry was mixed by ball milling for the next $30 \mathrm{~min}$. The slurry was cast at $25^{\circ} \mathrm{C}$ by a tape cast machine (CC1200 , Mistler) with moving polyethylene terephthalate carrier film coated with a fine silicon layer (Mylar G10JRM, Mistler). A casting speed of $6 \mathrm{~cm} / \mathrm{min}$ was used. The gap between the blade and the carrier was set manually to obtain a final tape thickness of 90 to $200 \mu \mathrm{m}$. The green tapes were dried at $25^{\circ} \mathrm{C}$ for $24 \mathrm{~h}$. Table 1 shows the composition of the two different slurries. Only the binder content was varied. The chosen slurry composition (powder and additives contents) was presented in [16].

Two tapes were laminated and arranged as follows: one in the cast direction and the other perpendicular to the cast direction. Lamination was carried in a warm press between two metal plates. In order to investigate the adequate conditions for a good adhesion between tapes, pressure $(P)$, time $(t)$, and temperature $(T)$ were varied as shown in Table 2. A $2^{3}$ factorial experimental design was carried out in order to choose the best combination of $P, T$, $t$, as shown in Table 3 .

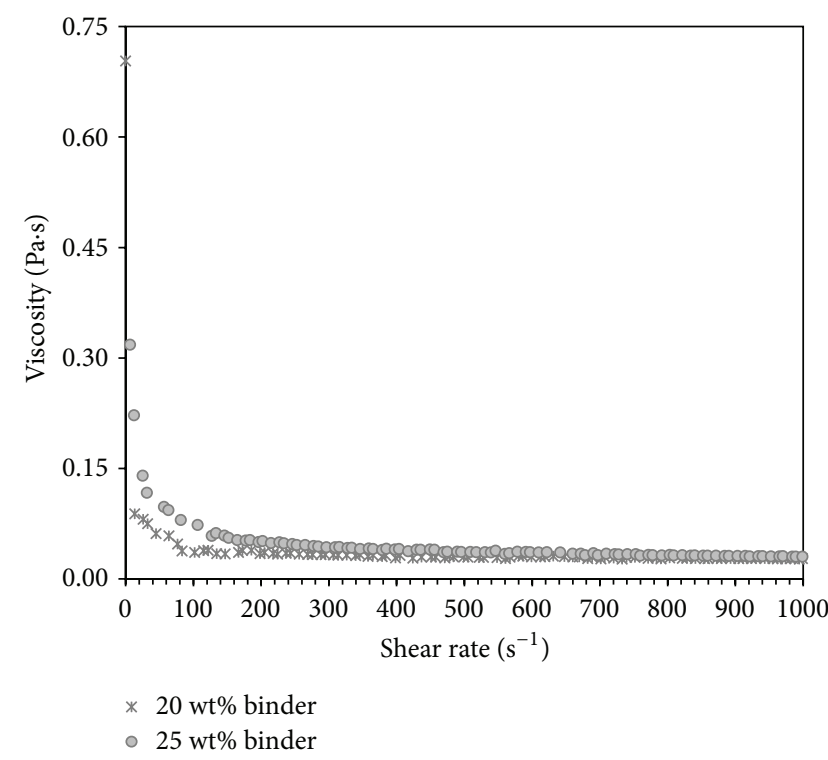

FIgURE 1: Viscosity versus shear rate of slurries with $20 \mathrm{wt} \%$ and $25 \mathrm{wt} \%$ binder.

The different $P, T$, and $t$ levels were chosen according to the previous experience of the research group. Five samples were laminated for each combination. The microstructure of green laminates was analyzed by scanning electron microscopy (SEM XL 30, Philips). Densities of the green tapes were measured geometrically and by Archimedes method. Open porosity and theoretical density were calculated from the bulk and Archimedes density. A texturometer (TA-XT2i, Stable Micro System) was used to measure the mechanical properties of the green tapes with a crosshead speed of $5 \mathrm{~mm} \mathrm{~min}^{-1}$ based on the ISO 527-3 norm [16]. For those mechanical tests, rectangular specimens $(100 \times 25 \mathrm{~mm}, 15$ samples) were cut using a blade.

\section{Results and Discussions}

3.1. Slurry Characterization. The viscosity versus shear rate curves of the slurries containing $20 \mathrm{wt} \%$ and $25 \mathrm{wt} \%$ binder is shown in Figure 1. It can be observed that there is a decrease of the viscosity of the slurries by increasing the shear rate. Both slurries showed similar shear-thinning behavior, but the one with $25 \mathrm{wt} \%$ presented a higher viscosity. Tape casting slurries are expected to present a shear-thinning behavior to produce films with a homogeneous and smooth surface. A slip with shear-thinning behavior decreases its viscosity under the shear rate produced by the blade, and after passing through the blade, the shear rate is released and the viscosity increased $[17,18]$. Nevertheless, some compositions could not avoid generating defects in the final green tape after drying, such as cracks and bubbles. During tape casting process, the shear rate imposed by the blade was determined as $5 \mathrm{~s}^{-1}$. In Figure 1, the rheograms show viscosity values of $\sim 0.10 \mathrm{~Pa} \cdot \mathrm{s}$ and $0.30 \mathrm{~Pa} \cdot \mathrm{s}$, respectively, for $20 \mathrm{wt} \%$ and $25 \mathrm{wt} \%$ binder. At higher shear rates both compositions presented similar viscosities. When passing through the blade, the viscosity 


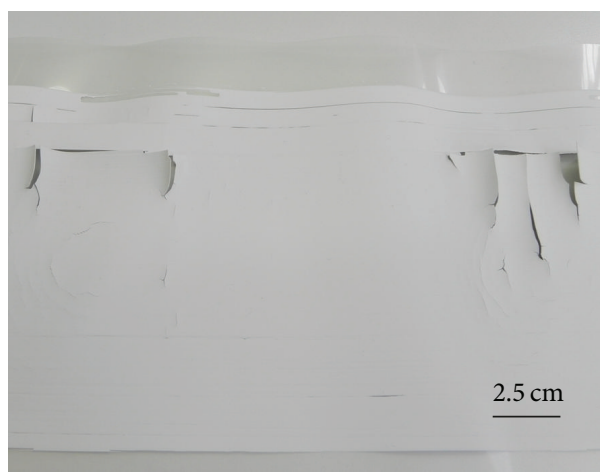

(a)

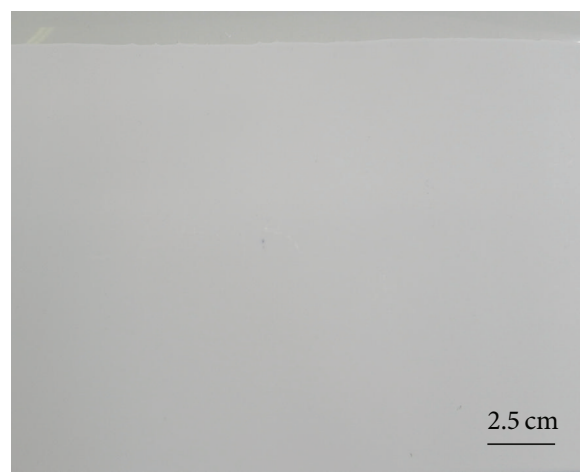

(b)

FIGURE 2: Green tapes after $24 \mathrm{~h}$ drying: (a) $20 \mathrm{wt} \%$ binder; (b) $25 \mathrm{wt} \%$ binder.

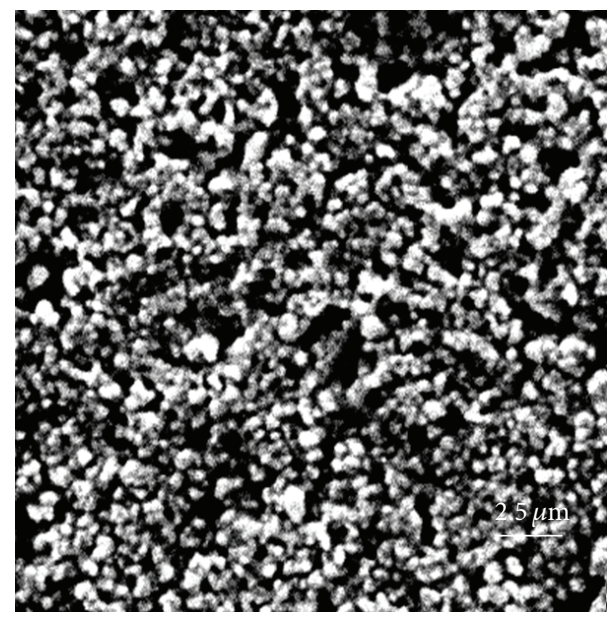

(a)

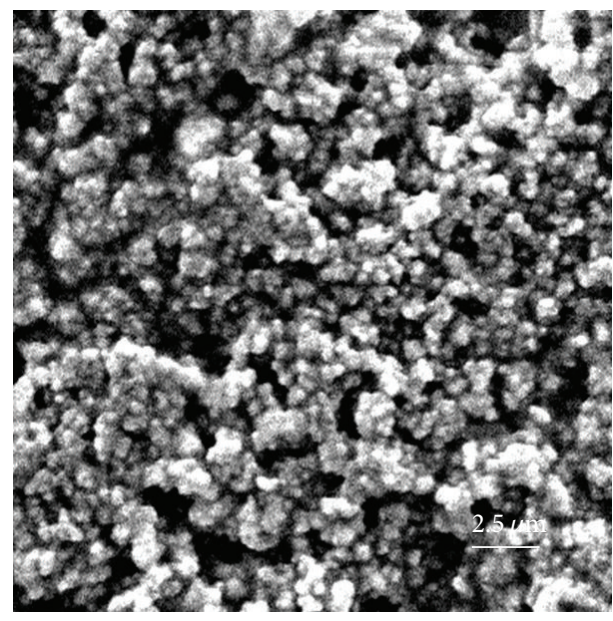

(b)

FIGURE 3: Microstructure of green tapes: (a) $20 \mathrm{wt} \%$ binder; (b) $25 \mathrm{wt} \%$ binder.

of the slurry with $25 \mathrm{wt} \%$ binder is slightly higher than that of the $20 \mathrm{wt} \%$ binder slurry, though. Slurries with higher viscosity values produce tapes with lower green density [17]. However, the slurries with $20 \mathrm{wt} \%$ and $25 \mathrm{wt} \%$ binder had an adequate behavior when just the tape casting step is considered.

In order to choose the most suitable composition, both slurries were cast under the same conditions on a polymer carrier with and without silicon coating. Figure 2 presents the tape surfaces of both compositions after $24 \mathrm{~h}$ drying. It can be seen from Figure 2(a) that the tape cast with the $20 \mathrm{wt} \%$ binder exhibited large cracks and a poor flexibility, whereas $25 \mathrm{wt} \%$ binder tape showed a smooth and homogeneous surface, as presented in Figure 2(b).

SEM features of the surface of the green tapes are presented in Figure 3. It can be seen that both microstructures are relatively homogeneous. There are some small pores, but no large defects can be observed. The microstructure of the green tape with $25 \mathrm{wt} \%$ binder presented a surface with joined particles that can be attributed to the higher content of binder compared with the green tape with $20 \mathrm{wt} \%$ binder.

3.2. Characterization of Green Tapes. Preliminary evaluation of the green tapes showed that the $20 \mathrm{wt} \%$ binder tape was not suitable to be laminated, due to the poor flexibility and the defects exhibited after drying as shown in Figure 2. Lamination was performed according to Table 3 , and it was noticed that four different combinations of pressure, temperature, and time showed the highest density of all green laminates. Of the 8 different parameter combinations (Table 3) only 4 laminates reached a green density above $50 \%$. Figure 4 presents the percentage of theoretical density of the best four conditions to laminate the sheets. It can be seen that density values varied between $51 \%$ and $54 \%$. Figure 4 shows that temperature and time have no significant effect on the green density, whereas pressure seems to affect more considerably the laminates green density. Although higher pressures can promote better adhesion between layers, it was observed that they also 
TABLE 4: Mechanical properties of green tapes (A: parallel and B: perpendicular to casting direction) and green laminate (L).

\begin{tabular}{lcccc}
\hline Sample & Tensile strength $(\mathrm{MPa})$ & Elongation $(\%)$ & Young's modulus $(\mathrm{MPa})$ & Thickness $(\mu \mathrm{m})$ \\
\hline A & $1.53 \pm 0.17$ & $5.70 \pm 0.87$ & $1.08 \pm 0.24$ & $130 \pm 8$ \\
B & $1.52 \pm 0.16$ & $4.41 \pm 0.52$ & $0.94 \pm 0.23$ & $130 \pm 8$ \\
L & $1.56 \pm 0.18$ & $5.63 \pm 0.64$ & $0.64 \pm 0.27$ & $220 \pm 12$ \\
\hline
\end{tabular}

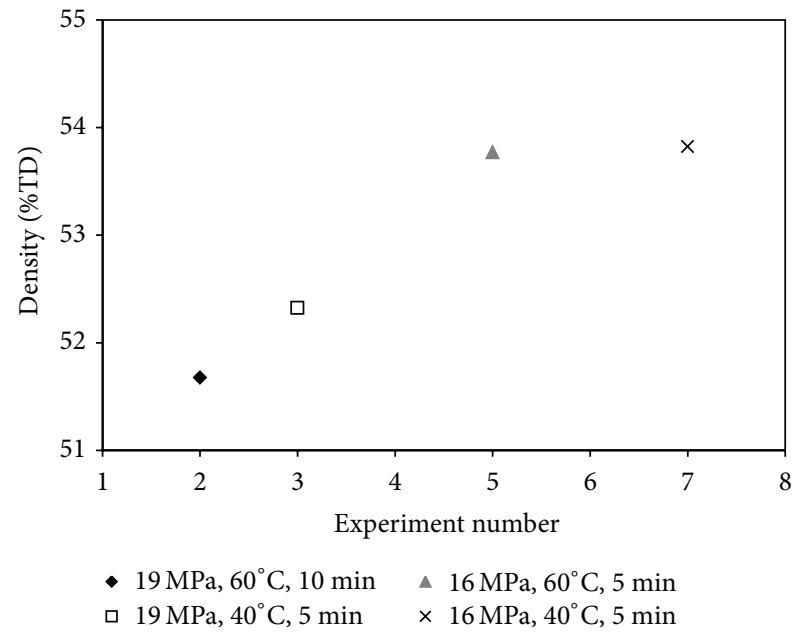

FIGURE 4: Relative density (\% theoretical density) of the green laminates at the 4 better conditions.

produce air bubbles between sheets. Suitable lamination conditions must provide homogeneous junction between layers, promoting diffusion between tapes and leading to high green densities. Eventually warm pressing produces inhomogeneous pressure distribution along the piece. In this work, higher pressure (i.e., $16 \mathrm{MPa}$ ) resulted in formation of bubbles between layers due to the gradient of pressure generated during lamination. These bubbles prevent the homogeneous junction between layers so that lower green densities were produced. The maximum density achieved was $\sim 54 \%$ at a $16 \mathrm{MPa}, 40^{\circ} \mathrm{C}$, and $5 \mathrm{~min}$. Higher green density results in higher tensile strength in the final product $[1,19]$. Gomes et al. [19] produced tapes from a ceramic vitreous material (LSZA) and they found that single tapes with the highest density $\left(1.45 \mathrm{~g} / \mathrm{cm}^{3}\right)$ showed the highest tensile strength values $(5.6 \pm$ $0.1 \mathrm{MPa})$.

The green tensile strength, elongation strain, Young's modulus, and thickness of single green tapes in two different orientations (A: parallel and B: perpendicular to casting direction) and two laminated tapes (L) were measured and the results are presented in Figure 5 and Table 4. From the results it is possible to observe that even though the tensile strength of single green tapes was similar, the samples measured in the direction of casting exhibited higher values, due to particle rearrangement in the polymer matrix. During processing, particles and polymer chains rearranged in the direction of casting providing higher mechanical strength to samples when measured in the same direction. Single layer samples presented a thickness of $130 \mu \mathrm{m}$, whereas the laminated samples were $220 \mu \mathrm{m}$ thick. In Figure 5, it can be

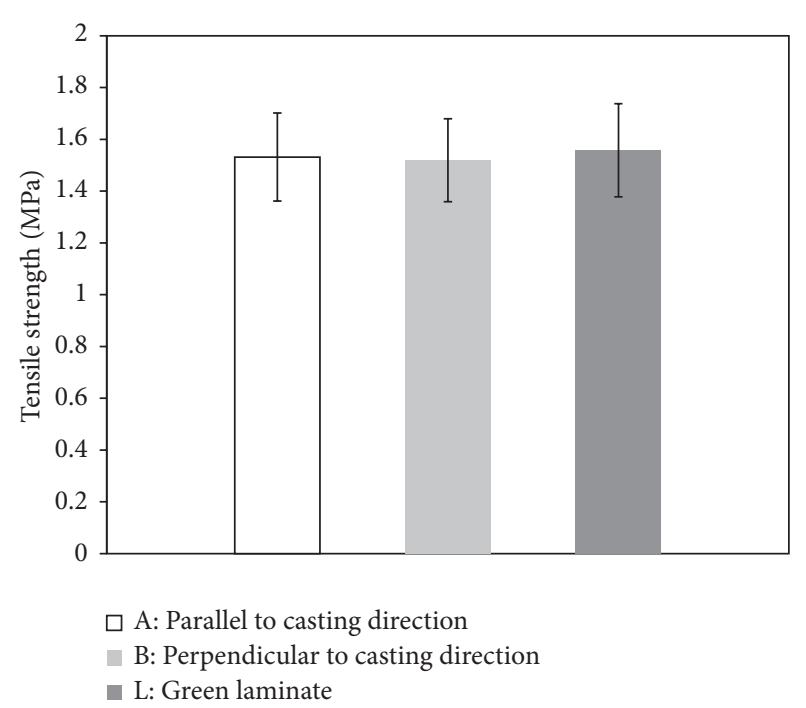

FIGURE 5: Tensile strength of single green tapes (A: parallel and B: perpendicular to casting direction) and green laminate (L).

seen that the laminated samples showed the highest tensile strength $(\sim 1.56 \mathrm{MPa})$, as expected. Compared to laminates, single tapes presented lower relative density of about $46 \pm$ $3 \%$. This fact also influences the mechanical strength results, because higher densities provide better mechanical properties to materials. The difference between the density of single tape samples and laminates could be attributed to the diffusion during laminating process and the rearrangement of the particles in the polymeric phase.

\section{Conclusions}

Aqueous tape casting is an alternative technique to produce flat yttria-stabilized zirconia for electrolyte-supported solid oxide fuel cell. Suitable tapes from slurry with $25 \mathrm{wt} \%$ acrylic emulsion binder were successfully prepared. Slurries with $25 \mathrm{wt} \%$ binder showed shear-thinning behavior, with a viscosity of $\sim 0.3 \mathrm{~Pa} \cdot \mathrm{s}$ when passing through the blade during tape casting. A smooth and homogeneous tape surface was produced. Lamination conditions were determined in order to obtain laminates with higher green densities. Adequate laminating conditions $\left(16 \mathrm{MPa}, 40^{\circ} \mathrm{C}\right.$, and $5 \mathrm{~min}$ ) were found and laminates with $54 \%$ theoretical density were obtained. Laminates showed slightly higher tensile strength of $1.56 \pm$ $0.18 \mathrm{MPa}$ when compared to single tapes but also presented lower elongation to strain. When comparing the mechanical properties of single tapes, samples measured in the direction of casting showed higher mean values of tensile strength, 
elongation to strain, and Young's modulus, $1.53 \pm 0.17 \mathrm{MPa}$, $5.7 \pm 0.87 \%$, and $1.08 \mathrm{MPa}$, respectively. Lamination provides the increase of the relative density of the samples compared to the single tapes, improving the mechanical strength.

\section{Conflict of Interests}

The authors declare that there is no conflict of interests regarding the publication of this paper.

\section{Acknowledgment}

The authors gratefully acknowledge the financial support from the CNPq Foundation, Brazil.

\section{References}

[1] F. Doreau, G. Tarì, M. Guedes, T. Chartier, C. Pagnoux, and J. M. F. Ferreira, "Mechanical and lamination properties of alumina green tapes obtained by aqueous tape-casting," Journal of the European Ceramic Society, vol. 19, no. 16, pp. 2867-2873, 1999.

[2] M. P. Albano and L. B. Garrido, "Influence of the slip composition on the properties of tape-cast alumina substrates," Ceramics International, vol. 31, no. 1, pp. 57-66, 2005.

[3] H. Moon, S. D. Kim, S. H. Hyun, and H. S. Kim, "Development of IT-SOFC unit cells with anode-supported thin electrolytes via tape casting and co-firing," International Journal of Hydrogen Energy, vol. 33, no. 6, pp. 1758-1768, 2008.

[4] M. P. Albano and L. B. Garrido, "Aqueous tape casting of yttria stabilized zirconia," Materials Science and Engineering A, vol. 420, no. 1-2, pp. 171-178, 2006.

[5] M. P. Albano and L. B. Garrido, "Influence of the slip composition on the aqueous processing and properties of yttria stabilized zirconia green tapes," Ceramics International, vol. 32, no. 5, pp. 567-574, 2006.

[6] Y. Zhang and J. Binner, "Tape casting aqueous alumina suspensions containing a latex binder," Journal of Materials Science, vol. 37, no. 9, pp. 1831-1837, 2002.

[7] J. Feng and F. Dogan, "Aqueous processing and mechanical properties of PLZT green tapes," Materials Science and Engineering A, vol. 283, no. 1-2, pp. 56-64, 2000.

[8] H. Jantunen, T. Hu, A. Uusimäki, and S. Leppävuori, “Tape casting of ferroelectric, dielectric, piezoelectric and ferromagnetic materials," Journal of the European Ceramic Society, vol. 24, no. 6, pp. 1077-1081, 2004.

[9] P. Vozdecky and A. Roosen, "Direct tape casting of nanosized $\mathrm{Al}_{2} \mathrm{O}_{3}$ slurries derived from autogenous nanomilling," Journal of the American Ceramic Society, vol. 93, no. 5, pp. 1313-1319, 2010.

[10] D. Hotza and P. Greil, "Review: aqueous tape casting of ceramic powders," Materials Science and Engineering A, vol. 202, no. 1-2, pp. 206-217, 1995.

[11] T. Chartier and A. Bruneau, "Aqueous tape casting of alumina substrates," Journal of the European Ceramic Society, vol. 12, no. 4, pp. 243-247, 1993.

[12] A. Kristoffersson and E. Carlström, "Tape casting of alumina in water with an acrylic latex binder," Journal of the European Ceramic Society, vol. 17, no. 2-3, pp. 289-297, 1997.

[13] Y. Zhang, C. Qin, and J. Binner, "Processing multi-channel alumina membranes by tape casting latex-based suspensions," Ceramics International, vol. 32, no. 7, pp. 811-818, 2006.
[14] L. Xibao, "Aqueous tape casting of SDC with a multifunctional dispersant," Journal of Ceramic Processing Research, vol. 13, pp. 324-329, 2012.

[15] Y. Cho, J. Yeo, Y. Jung, S. Choi, J. Kim, and U. Paik, "Effect of molecular mass of poly(vinyl butyral) and lamination pressure on the pore evolution and microstructure of $\mathrm{BaTiO}_{3}$ laminates," Materials Science and Engineering A, vol. 362, no. 1-2, pp. 174180, 2003.

[16] V. Moreno, J. L. Aguilar, and D. Hotza, "8YSZ tapes produced by aqueous tape casting," Materials Science Forum, vol. 727-728, pp. 752-757, 2012.

[17] R. Moreno, "The role of slip additives in tape-casting technology, part II: binders and plasticizers," American Ceramic Society Bulletin, vol. 71, pp. 1647-1657, 1992.

[18] Y. Qiao, Y. Liu, A. Liu, and Y. Wang, "Boron carbide green sheet processed by environmental friendly non-aqueous tape casting," Ceramics International, vol. 38, no. 3, pp. 2319-2324, 2012.

[19] C. M. Gomes, A. P. N. Oliveira, D. Hotza, N. Travitzky, and P. Greil, "LZSA glass-ceramic laminates: fabrication and mechanical properties," Journal of Materials Processing Technology, vol. 206, pp. 194-201, 2008. 

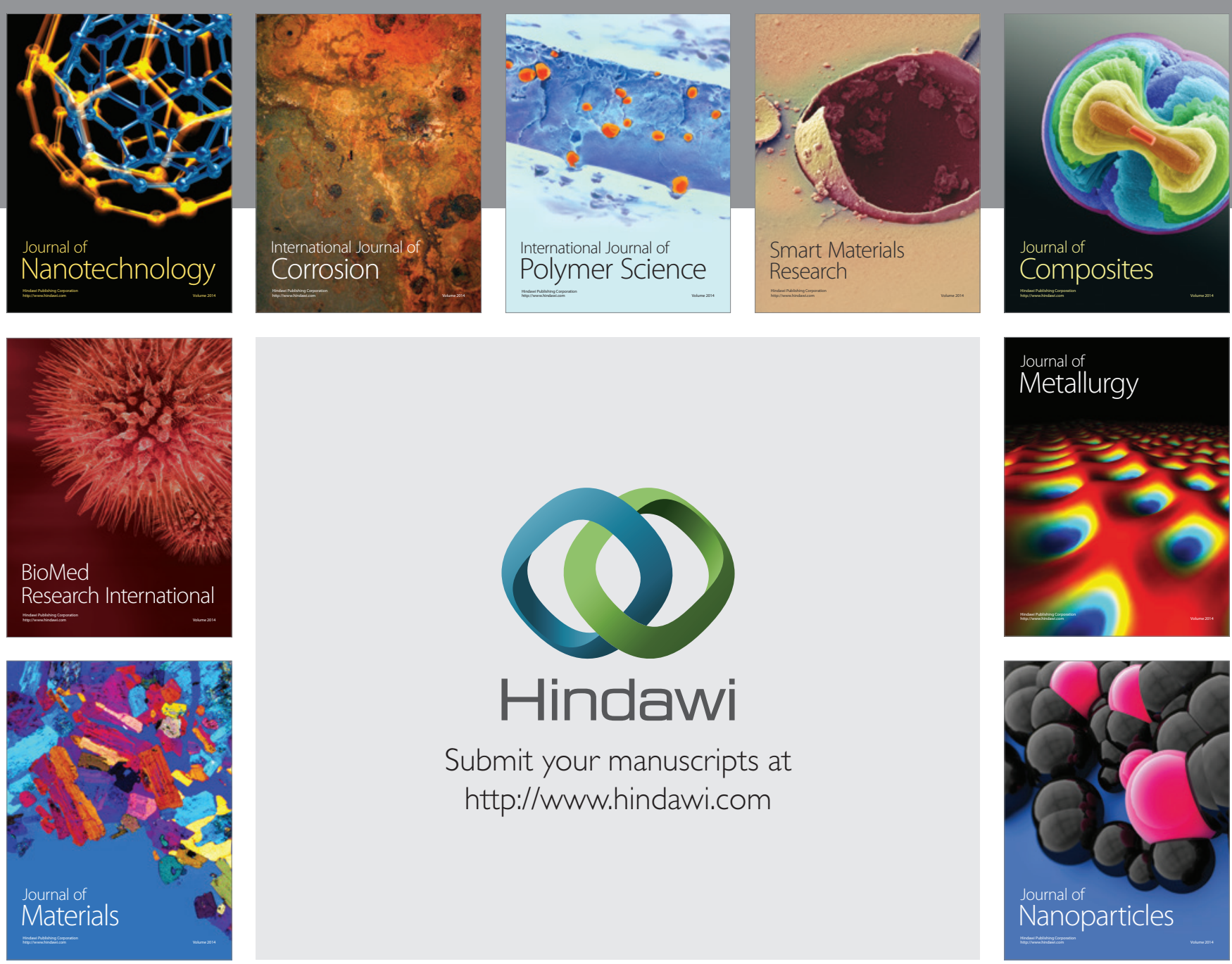

Submit your manuscripts at http://www.hindawi.com
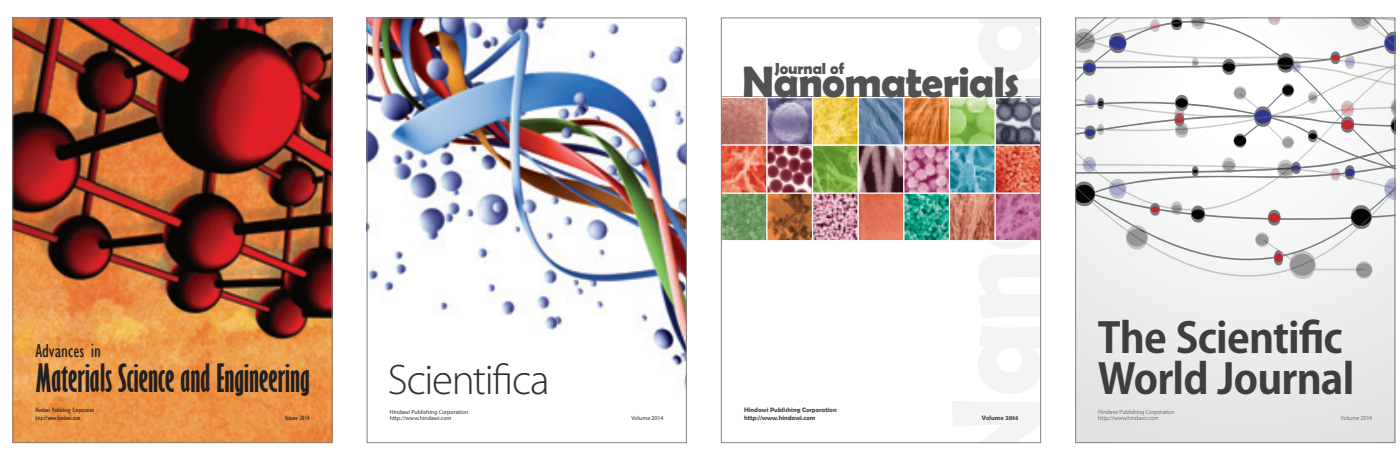

\section{The Scientific World Journal}
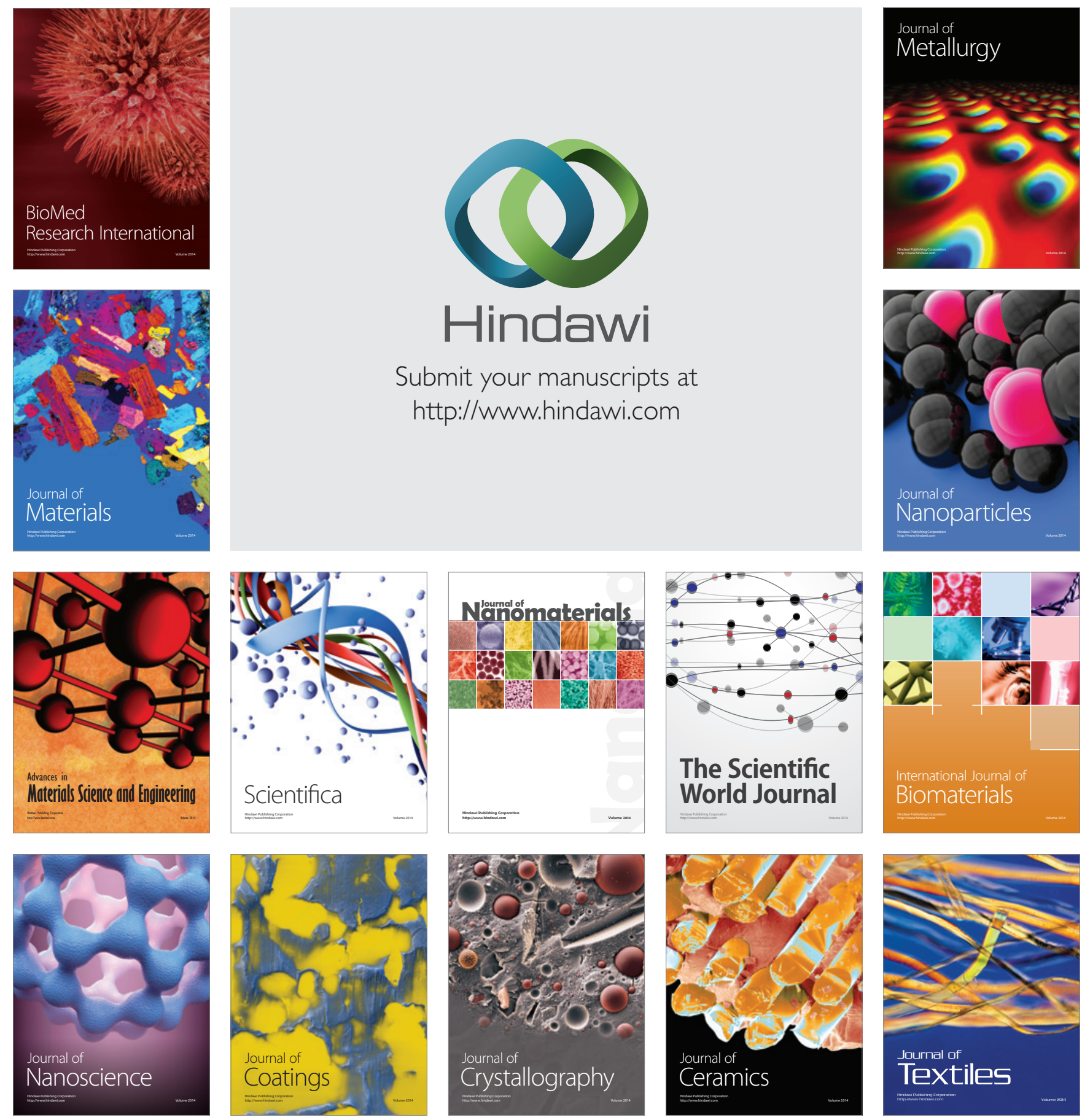